\title{
Assessment of dairy cattle husbandry and breeding management practices of lowland and mid-highland agro-ecologies of Borana zone
}

\author{
Dejene Takele Gebissa \\ Oromia Agricultural Research Institute, Yabello Pastoral and Dryland Agriculture Research Center, Yabello, Ethiopia \\ Email address: \\ yomlatadtg@gmail.com
}

To cite this article:

Dejene Takele Gebissa. Assessment of Dairy Cattle Husbandry and Breeding Management Practices of Lowland and Mid-Highland Agro-Ecologies of Borana Zone. Animal and Veterinary Sciences. Vol. 2, No. 3, 2014, pp. 62-69. doi: 10.11648/j.avs.20140203.12

\begin{abstract}
This survey was carried out in Borana zone to assess the existing breed/breed strain and herd structure, husbandry practices for the animal, rate of inbreeding, and reproductive and productive performance of dairy cattle. Hence, various strains of Borana cattle and cattle type of neighboring adjacent zone, namely Qorti, Geleba, cross of Qorti and Geleba, Guji and Konso subtype, were observed, except non existence of Konso in mid-highland, in both agro-ecologies. Qorti was the true and preferred cattle strain for its potential milk production capacity however it was at decreasing trend due to the feed shortage resultant from the change in climatic condition combined with shrinkage of grazing land. Respectively, the coefficient of inbreeding was 0.0059 and 0.0088 for the lowland and mid-highland area which seemed to be less than the maximum acceptable level however the prevalence of inbreeding was inhabitable as long as there was uncontrolled mating practice. The average age of sexual maturity, calving interval, reproductive life time and crops of calves during the life time of female were 3.9 and 3.7 years, 16.8 and 13.8 months, 11.5 and 10.9 years, and 7.1 and 6.6 calves in the lowland and mid-highland area, respectively. Average age of sexual maturity and the reproductive life time of the breeding bull were 4.6 and 4.2, and 9.86 and 7.68 years in the lowland, and mid-highland areas, respectively. Milk production of both agro-ecologies and the seasons of the year were characterized by paramount variation and hence a cow could produce daily 1.85 and 1.10 liter during the wet, and 0.35 and 0.95 liter during the dry season from the lowland and mid-highland area, respectively. Therefore, the higher proportion of cows and young animals in the herd endeavor large crops of calves for rapid herd growth and enhance cattle productivity of the country, provided that there is appropriately and efficiently enacting of multifaceted strategies to improve the reproductive performance and combat the danger of genetic dilution from cattle type of adjacent zone, and the problem of feed shortage and nutritive value deterioration.
\end{abstract}

Keywords: Dairy Cattle, Husbandry Practice, Reproductive and Productive Performance, Lowland and Mid-Highland Area of Borana Zone

\section{Introduction}

Pastoralism and agro-pastoralism are the dominant livestock production-based, land-use systems in the arid agro-ecologies of Ethiopia and account for $50 \%$ of the total 114 million livestock numbers, out of which $40 \%$ of cattle, $52 \%$ sheep, $56 \%$ of goats and $100 \%$ of camels are originated from this area (ACTESA, 2011). Like in other pastoral and agro-pastoral production system livestock production forms the basis of the economy, specially the main source of food and income supporter of Borana zone. Depending on the purpose to keeping the animal, climatic factors, availability of pasture and water, and cultural practices, Borana pastoralists are dealing with different types of livestock management practices like herd mobility, herd splitting, feeding and watering, and breeding which have direct and/or indirect influence on the productivity regardless of the variation in the magnitude and intensity (Ayana Angassa and Fekadu Beyene, 2003).

Borana cattle and other cattle type of neighboring zone are the predominant species and strain of cattle which are reared for various purposes (Zelalem Nemera, 2012). Though the total herds of cattle in the study area are at increasing trend, heads of cattle per household owning are at dramatic decrement. The decrement in the trend might be due mainly to the adverse climatic condition and grazing land degradation in the lowland and expansion of cropping 
activity in the mid-highland agro-ecology. Variation in the trend of heads of cattle per household and total population in the lowland is mostly resulted from the high population growth rate of the area.

Cattle which are characterized by varying production and reproduction performance are primarily kept for milk production in the lowland area, where as they are kept for traction on the top of milk in the mid-highland area. For instance, the study conducted by Ababu Dekeba et al. (2006) at Abernosa ranch indicated that Borana cows have longer calving interval and 36 to 45 months of age for first calving. At Muguga, Kenya age at first heat, at first service and at first calving for Borana cattle were reported to be 15.6, 21.7 and 32.2, respectively (Okeyo et al., 1998). However, little was known about their productive and reproductive performance at their native habitat. This study was, therefore, conducted to document the current traditional knowledge on dairy cattle husbandry and breeding practices in the lowland and mid-highland of Borana zone in an endeavor to determine what its role might be in developing future systems of dairy cattle use.

\section{Materials and Methods}

\subsection{Description of Study Area}

The Borana zone is found at the south part of the Ethiopia occupying a total land area of about $95,000 \mathrm{~km}^{2}$. The zone is ecologically classified in to the lowland and mid-highland based on their agro-ecologies. The lowland area is mostly characterized by livestock production while it is mixed farming of livestock rearing and cropping in mid-highland where grazing land is predominantly communal with emerging privatization of crop and Kallo, and purely privatization in the lowland and mid-highland, respectively. Rainfall delivery is bimodal; with the long rains accounting for $60 \%$ of the total rainfall falling between March and May and the short rains comprising of $27 \%$ of the total rainfall falling between September and November with an average annual rainfall varying from 353 to $900 \mathrm{~mm}$ per annum in the lowland (Kamara A., 2004) and 900 to $1400 \mathrm{~mm}$ in the mid-highland (Data of National Meteorological Agency, Awassa Branch Directorate).

\subsection{Sampling Procedure for Sites and Respondents Selection}

The districts of the zone were selected based on its representativeness to the lowland and mid-highland agroecologies of the zone. Accordingly, a total of 2 districts from mid-highland area (Bule Hora and Gelana) and 4 districts from lowland area (Teltelle, Yebello, Arero and Moyale) were selected. Study area selection was carried based on the secondary data that was gathered from zonal development office and other stakeholders. Stratifying according to its proximity to market two kebeles was selected from the respective district. Fifteen household heads was selected from each kebele to be interviewed.

\subsection{Data Collection Methods}

The study was conducted employing formal survey while structured questionnaire was prepared and commencing actual data collection, information on management practices provided to various categories dairy cattle was assessed. Similarly, the existing breed and breed strain under the context of lowland and mid-highland community; herd structure; trend in breed population; breeding management (selection criteria, source of breeding bull, culling criteria and mating system); indigenous description to the breed, and purpose of keeping cattle was collected. Rate of inbreeding was calculated from effective number of breeding animals of both agro-ecologies. The base line data on the reproductive and productive potential of dairy cattle was also assessed. As such the age of sexual maturity of both sex; the fertility and mothering ability of the dairy cow; the lactation length; the calving interval; the life time production and reproduction/ calving potential of cow and service year of bulls, and any problems related with the production and reproduction was surveyed. To validate the information obtained from individual interview, PRA and focus group discussions were conducted with elderly pastoralists who were known to have better knowledge on the present and past social and economic status of the study area.

\subsection{Data Management and Statistical Analysis}

The computer software so called Statistically Package for Social Science (SPSS of Version 20) was employed to analysis the data. For the accurate conclusion that is going to be stated, T-test and chi-square was carried out to assess statistical significance or for particular comparison. An indices were calculated for all ranking data using the formula: Index $=\Sigma$ of [ 3 for rank $1+2$ for rank $2+1$ for rank 3] given for an individual reason/criteria divided by $\Sigma$ of [3 for rank $1+2$ for rank $2+1$ for rank 3] for overall reasons/criteria. Employing the formula designed by Falconer and Mackay (1996), level of inbreeding was determined with the inbreeding coefficient $(\Delta \mathrm{F}=1 /(2 \mathrm{Ne}))$. Where, $\Delta \mathrm{F}=$ inbreeding coefficient; $\mathrm{Ne}=$ effective population number. On the other hand, $\mathrm{N}_{\mathrm{e}}=4 \mathrm{~N}_{\mathrm{m}} \mathrm{N}_{\mathrm{f}} / \mathrm{N}_{\mathrm{m}}+$ $\mathrm{N}_{\mathrm{f}}$. Where, $\mathrm{N}_{\mathrm{m}}=$ number of breedable male and $\mathrm{N}_{\mathrm{f}}=$ number of breedable female.

\section{Results and Discussion}

\subsection{Cattle Holding and Herd structure of Borana Zone}

The community reported during the focus group discussion that their livelihood was directly and/or indirectly reliant of livestock production. The livestock was playing a great role in economic and social aspect of agroecology were cattle, small ruminants, camel, donkey, chicken, mule and horse (specific to mid-highland). Of those cattle held the prime share in milk production followed by the recently emerging camel. The community 
categorized their cattle in different herd structure based on the age and sex of the animal and hence cow, heifer with 1 to 3 and 4 to 5 years old, bull of greater 5 years old, female and male calf of less than 1 year old, steer of 1 to 4 years old, and ox. Hence, the response of the community on cattle herd composition per household also indicated that on average $12.9,9.7,8.2,3.8,3.6,11.4,5.7$ and 3.1 in low lowland, and 8.6, 4.9, 2.3, 3.3, 2.8, 3.4, 3.6 and 3.1 of their herd in mid-high land area was cow, heifer $(1-3$ years $)$, bull $(>5$ years $)$, female calf $(<1$ year old $)$, male calf $(<1$ year old $)$, steer $(1-4$ years old $)$, heifer $(4-5$ years old $)$ and ox, respectively (Table 1). Higher proportion of cows and young animals in the herd marks the significance of cattle production as the most important enterprise and large crops of calves and hence rapid herd growth and potential milk production expectation. The observed variation for oxen holdings of both agro-ecologies was probably due to the fact that the lowland residents gave more attention to bulls for market in lowland area whereas the mid-highland population probably needed the oxen as source of draught power for crop production.

Table 1. Herd size of various composition and TLU per household of Borana Zone.

\begin{tabular}{lllll}
\hline Herd composition per house hold & $\begin{array}{l}\text { Lowland } \\
\text { Range }\end{array}$ & Mean \pm SD & $\begin{array}{l}\text { Mid-highland } \\
\text { Range }\end{array}$ & Mean \pm SD \\
\hline Number of Cow & $1-150$ & $12.9 \pm 2.4$ & $1-60$ & $8.6 \pm 1.5$ \\
Number of Heifer 1-3 Yrs & $1-150$ & $9.7 \pm 2.3$ & $1-30$ & $4.9 \pm 0.8$ \\
Number of Bulls $>5$ Yrs & $0-225$ & $2.2 \pm 3.8$ & $1-7$ & $1.8 \pm 1.6$ \\
Number of Female calf $<1 \mathrm{Yr}$ & $1-25$ & $3.8 \pm 0.5$ & $1-33$ & $3.3 \pm 0.8$ \\
Number of Male calf $<1 \mathrm{Yr}$ & $1-25$ & $3.6 \pm 0.5$ & $1-20$ & $2.8 \pm 0.6$ \\
Number of Steer 1-4Yrs & $1-70$ & $11.4 \pm 3.5$ & $1-10$ & $3.4 \pm 0.6$ \\
Number of Heifer 4-5Yrs & $1-50$ & $5.7 \pm 1.2$ & $1-30$ & $3.1 \pm 0.6$ \\
Number of oxen & $0-13$ & $1.1 \pm 5.3$ & $1-10$ & $2.42 \pm 0.24$ \\
Number of breeding bull & $0-30$ & $2.7 \pm 0.4$ & $0.8-8$ & $2.4 \pm 1.6$ \\
TLU/Household & $2-17$ & $15.8 \pm 2.4$ & \\
\hline
\end{tabular}

$\mathrm{N}$ refers to number of respondents, Yrs refers to years, SD refers to Standard Deviation and TLU refers to Total Livestock Unit that is equals to 0.8 for 1 head of cattle.

The current survey also revealed that total cattle herd size per household for lowland was significantly higher than those in the mid-highland area. The previous report showed that an average cattle holding per household for the lowland of Borana Zone is estimated to be 16.9 TLU (Adugna Tolera and Aster Abebe, 2007) which is almost similar to the current survey that indicated an average of 15.8 and 2.4 TLU per household of lowland and midhighland areas, respectively, but there was a decline in trend. The higher total cattle herd size in low land area is probably due to the presence of relatively larger communal grazing land and the mode of their livelihood support is purely pastoralism to agro-pastoralism that is nearly dependent up on livestock rearing. The aggregated herd size per household was unevenly distributed among the households showing a strong skewing towards the poorer of both agro-ecologies (Table 1). The decline in cattle herd size per household was in line with the reports of the studies conducted by Desta and Coppock (2002) and Angassa and Oba (2007) those concluded that there would be declining trend in cattle holding per household in the Borana pastoral system induced by loss of animals because of the frequently recurring droughts combined with other factors such as increased human population and land use changes.

The lowland and mid-highland of Borana zone were rearing Borana cattle strains and cattle type of neighboring zone whose proportions were varying depending on the agro-ecologies they were living in and the wealth status of the community as summarized in Figure 1.

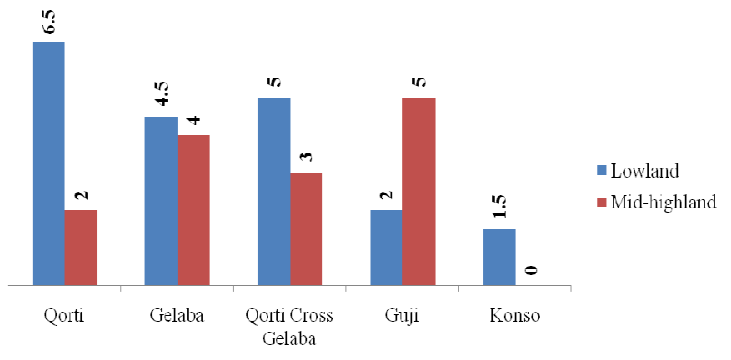

Figure 1. Borana Cattle Strain and Cattle Type of Neighboring Zone Possession per Household of Borana Zone.

Consequently, the average per household owning of Qorti, Geleba, Qorti cross Geleba, Guji and Konso subtype in lowland area were $6.5,4.5,5,2$ and 1.5, correspondingly, whereas in the mid-highland area they were merely Qorti, Geleba, Guji and Qorti cross Geleba subtype with the average per household owning of 2, 4, 3 and 5 animals, respectively.

Even though, respectively, $89.8 \%$ and $88.5 \%$ of the lowland and mid-highland respondents believed that Qorti were the true strain, $77.3 \%$ of the lowland and $62.5 \%$ of mid-highland felt that the trend for Qorti was decreasing. The trend for Gelaba was the reverse in that it was increasing according to $65.4 \%$ of the respondents of lowland and mid-highland areas (Table 2). The variation in the trend of the two strains in lowland area could be the relatively less coping up of Qorti to the dramatically fluctuating climatic conditions which have been deteriorating the quantitative and qualitative availability of feed resources which have the direct impact on the survival 
and productivity of the animal as well. However, there were controversial views in mid-highland on the trend of Gelaba since $40.9 \%, 31.8 \%$ and $27.3 \%$ of the respondents believed that it was at increasing, decreasing and stable trend, respectively.

Table 2. Response of the participants on true Borana cattle strain, preference, and its trend in the lowland and mid-highland of Borana.

\begin{tabular}{llllllllllll}
\hline $\begin{array}{l}\text { Cattle } \\
\text { Strain }\end{array}$ & $\begin{array}{l}\text { True Borana Cattle Sub- Preferred Borana cattle sub- } \\
\text { type (\%) } \\
\text { Lowland }\end{array}$ & Mid-highland & $\begin{array}{l}\text { Type (\%) } \\
\text { Lowland }\end{array}$ & Mid-highland & Increasing & Decreasing & Stable & Increasing & Decreasing & Stable \\
\hline Qorti & 89.8 & 88.5 & 94.4 & 92.6 & 0 & 97.3 & 2.7 & 9 & 62.5 & 28.5 \\
Geleba & 8.3 & 11.5 & 5.6 & 7.4 & 65.4 & 4 & 30.6 & 40.9 & 31.8 & 27.3 \\
\hline
\end{tabular}

The preference for Qorti was against the decreasing production trend since $94.4 \%$ and $92.6 \%$ of the interviewee of the lowland and mid-highland areas, respectively, were in need to rear it (Table 2). The community was motivated to rear Qorti than other as they reasoned out that Qorti were better in milk and meat production, and fetching attractive price. However, because of better resistance to disease, and higher tolerance of feed and water shortage and drought outbreak of Gelaba than Qorti Subtype the rest $4.8 \%$ of the respondents lowland of area preferred for the former. The conducted PRA also revealed that the mid-highland respondents forced to depend solely on Geleba and Guji strain for lack of access to Qorti subtype, in addition to the aforementioned reasons.

\subsection{Breeding Strategies and Reproduction Mechanism of Borana Cattle}

Like in most parts of our country natural breeding with bull is common in the survey areas. On average $75 \%$ and $84.2 \%$ of interviewee of lowland and mid-highland areas, respectively, responded that they possessed the breeding bull (Table 3). The larger the figure of the respondents who did not own their breeding bull in the lowland areas is due to the fact that there has been the practice of herding in the communal grazing land where their herd can be mated by their neighbors' bull. Conversely, the grazing system in the mid-highland has been more of privately owned where their herd is rarely mated by others so that the respondents were forced to possess at least one bull that can be dually utilized for ploughing. Despite the larger the respondents who had the breeding bull in the mid-highland, per household possession of breeding bull in lowland (2.2) was statistically higher than mid-highland (1.7) at $\mathrm{P}<0.05$. The owners of more than one bulls around lowland area reasoned out for doing so that they utilized the bulls for free graze partial fattening, rearing as bull was relatively tolerant to feed and water shortage, and disease outbreak than other cattle category, and for traction purpose also. Similarly, those of the highland residents reasoned out for the mentioned purpose, mainly for the traction purpose since an area was predominantly practicing crop farming. All the respondents provided no special management for the breeding bull except those of cropping farmers of midhighland who managed bulls in enclosure after and before farming.

Table 3. Breeding bull holding and selection of breeding bull and female in Borana Zone.

\begin{tabular}{|c|c|c|c|c|c|c|}
\hline $\begin{array}{l}\text { Agro- } \\
\text { ecologies }\end{array}$ & $\begin{array}{l}\text { Breeding Bull } \\
\text { Owners (\%) }\end{array}$ & $\begin{array}{l}\text { Average breeding } \\
\text { bull/house hold }\end{array}$ & $\begin{array}{c}\text { Breeding } \\
\text { male selection } \\
(\%)\end{array}$ & $\begin{array}{c}\text { Breeding } \\
\text { female } \\
\text { selection }(\%) \\
\end{array}$ & $\begin{array}{l}\text { Age of selecting } \\
\text { breeding male } \\
\text { (Years) }\end{array}$ & $\begin{array}{c}\text { Age of selecting } \\
\text { breeding female } \\
\text { (Years) }\end{array}$ \\
\hline Lowland & 75 & 2.2 & 95.5 & 82.6 & 4.32 & 3.99 \\
\hline Mid-highland & 84.2 & 1.7 & 94.7 & 93 & 3.54 & 3.56 \\
\hline
\end{tabular}

The majority of the respondents (95.5 and $94.7 \%$ of the respondents of lowland and mid-highland, respectively) were also practicing selection of breeding male. Similarly, 82.6 and $93 \%$ of the respondents of lowland and midhighland were also practicing selection of breeding female, respectively. Most of the Borana communities of lowland agro-ecology were indigenously knowledgeable in selecting better performing breeding male and female at calf age while others were doing so at average age of selecting breeding male was 4.32 and 3.54 years in the lowland and mid-highland areas, respectively. Breeding female was selected at average age of 3.99 and 3.56 years in the lowland and mid-highland areas. The age selecting breeding male was significantly different for the lowland and highland areas. Reversely, there was no significant difference for the age of selecting breeding female of lowland and mid-highland areas $(\mathrm{P}<0.05)$. The earlier the age for selecting breeding male in the mid-highland might be for earlier differentiation of better performing in breeding and then safeguarding from not to be harmed by traction. The breeding male was selected based on the size, color, growth, age of sexual maturity, their growth performance, their horn orientation, their adaptability, their pedigree, and the ability of animal to walk long distance. Among the listed traits, the community emphasized the size of the animal, color of the animal, and libido and pedigree as the first, second and third criteria of selection, respectively, in the lowland areas. Characters like size, color and pedigree of the animals have been considered as the first, second and third criteria of selecting breeding male in the mid-highland areas of the survey site. Similarly, the character like their size, color, age at first sexual 
maturity, calving interval, longevity, adaptability, milk yield, ability to walk long distance, mothering character, pedigree and calf's survival and growth were the major ones that the community considered. However, they mainly utilized milk yield, calf survival and animal's pedigree, and size and mothering character of the animal as the first, second and third traits, respectively, for selection of breeding female in lowland areas. Reversely, size, milk yield, and pedigree and calf survival were the first, second and third criteria for selecting breeding female in the midhighland areas. The predominant type of adaptability that the respondents gave attention as criteria of breeding male and female selection were disease, drought, feed and water shortage, and heat tolerance.

The pastoral communities of lowland were seldom practicing seasonal breeding systems. Hence, wet season (May to July) was the usual time of breeding while the bull get feed and water to perform best or to maintain active Libido, and control inbreeding problems (by those practicing controlled mating). The response of the respondents indicated that the mating mechanism of their herd was uncontrolled system as their cattle was herd together on the communal grazing land and the community were in the shortage of the awareness about the merits of controlled mating. Even, the bull was allowed to mate his mother, daughter and sister which were dangerous phenomenon of causing inbreeding production. The culture of the community forced them to permit their bulls to serve females of other and in turn their females to be served by others bull in case they did not absolutely have their own bull or theirs was not attractive/good performing. These all were the predominant causes for inbreeding which was the risk of cattle production of the study areas. Even though it was lower than the maximum acceptable level of 0.063 (Armstrong, 2006), the computation of the rate of inbreeding coefficient $(\Delta \mathrm{F})$ from the response of the respondents confirmed that there was prevalence of inbreeding in both agro-ecologies Borana zone as presented in Table 4.

Table 4. Effective population size and level of inbreeding for both agro ecologies of Borana zone.

\begin{tabular}{lllll}
\hline Agro-ecologies & $\mathbf{N}_{\mathbf{f}}$ & $\mathbf{N}_{\mathbf{m}}$ & $\mathbf{N e}$ & $\mathbf{\Delta F}$ \\
\hline Lowland & 81.72 & 28.53 & 84.59 & 0.0059 \\
Mid-highland & 52.38 & 19.53 & 56.90 & 0.0088 \\
\hline
\end{tabular}

$\mathrm{N}_{\mathrm{f}}=$ breedable female; $\mathrm{N}_{\mathrm{m}}=$ breedable male; $\mathrm{N}_{\mathrm{e}}=$ effective population size and $\Delta \mathrm{F}=$ coefficient of inbreeding

Under random mating $\mathrm{Ne}$ and $\Delta \mathrm{F}$ were 84.59 and 0.0059 for the lowland and 56.90 and 0.0088 mid-highland cattle, respectively. The danger of inbreeding was lower for lowland than mid-highland area of Borana zone since there were collection of breedable male from various origin and thus widen the chance of breeding female to be served by different bulls in the former area and the privatization of grazing land in later area forced the herds of one household not to be mixed and hence mated with others.
The result of the survey indicated that about 70.3 and $97.2 \%$ of the respondents of lowland and mid-highland, respectively, were practicing castration of bulls. The significant discrepancy between the two agro-ecologies is due to the fact that in the mid-highland areas castration is the method of making stronger the animal for traction. The result of the survey also indicated almost all of the community in the lowland (96.3\%) and highland (98.2\%), respectively, practiced tradition castration methods. The respondents around lowland area practiced castration as they assumed that castration was means of controlling breeding, and improving meat fattening and price of the bulls. The participants of mid-highland area revealed that practicing castration was for castrated bulls were more powerful for traction. But those engaged in lowland were not practicing castration since now a day it was uncastrated bulls that were fetching better price while compared to those castrated. The main castration season for lowland and mid-highland was May to June and from October to November, respectively, as those seasons were the time when sufficient feed resource was available for the recovery of the bull. It was also probably due the fact that in mid-highland the season reduces harboring inconvenience for the castrated bull since it is relatively warmer temperature with reduced rain.

\subsection{Reproductive and Productive Performance of Borana Cattle}

The assessment of the reproductive performance of both agro-ecologies revealed that the average age at sexual maturity of breeding male and female was 4.6 and 3.9 years for lowland and 4.2 and 3.7 years for mid-highland area, respectively (Table 5). The findings for lowland part were almost in line with the report of Abebe Olkeba (2009) which confirmed male and female cattle of Borana zone were come to sexual maturity at an average of 4.4 and 3.7 years old. Indeed, it seemed almost approaching but the insignificant delay for cattle in mid-highland area were probably due to the difference in the strain identified in the areas.

All the respondents of mid-highland and about $78.4 \%$ of the lowland did not fix age at first mating of the male. Similarly, $58.6 \%$ and $59.6 \%$ of the respondents of lowland and mid-highland, correspondently, did not fix age at first mating of female. However, there were few of lowland respondents who fixed age of first mating of male by controlling from mating until it would achieve the desired age. They reasoned for fixing of was that animal with undermatured age were less productive than the age limitation fixed by the herder. The mean age of first calving of females was 4.9 and 4.8 years and calving interval was 16.8 and 13.8 months in the lowland and mid-highland area, respectively (Table 5). The presumed reasons for the shorter calving interval in the mid-highland might be for the availability of ample feed resources from crop residues and less prone of an area to recurrent drought while compared with the lowland. 
Table 5. Reproductive performance of dairy cattle across various agro-ecologies of Borana Zone.

\begin{tabular}{llll}
\hline Reproductive traits & Agro-ecology & N & Mean \pm SD \\
\hline \multirow{2}{*}{ Age of sexual maturity of male (Years) } & Low land & 109 & $4.57 \pm 0.06$ \\
& Mid-highland & 57 & $4.1 \pm 0.15$ \\
& Lowland & 98 & $3.94 \pm 0.07$ \\
Age of sexual maturity of female (Years) & Mid-highland & 57 & $3.73 \pm 0.14$ \\
& Lowland & 109 & $4.90 \pm 0.07$ \\
Age of first calving (Years) & Mid-highland & 57 & $4.84 \pm 0.13$ \\
& Lowland & 109 & $9.86 \pm 1.93$ \\
Reproductive life time of male (Years) & Mid-highland & 57 & $7.68 \pm 1.62$ \\
& Lowland & 109 & $11.50 \pm 0.33$ \\
Reproductive life time of female (Years) & Mid-highland & 57 & $10.86 \pm 0.46$ \\
& Lowland & 109 & $16.77 \pm 0.71$ \\
Calving interval (Months) & Mid-highland & 57 & $13.84 \pm 0.86$ \\
& Lowland & 109 & $8.77 \pm 0.71$ \\
Gestation length (Months) & Mid-highland & 57 & $8.84 \pm 0.86$ \\
\hline
\end{tabular}

$\mathrm{N}$ refers to Number of Respondents and SD refers to Standard Deviation

The reproductive life time of the breeding bull and female was 9.86 and 11.5 years in the lowland, and 7.68 and 10.9 years in mid-highland areas, respectively (Table 5). Though there was no statistically significant discrepancy for female of both agro-ecologies, it was significantly different $(\mathrm{P}<0.05)$ for male. That was, perhaps, due to the fact that, in addition to breeding, males are employed for traction purpose which shorten their lifespan in midhighland.

The assessment of the productive performance revealed that with the aforementioned reproductive life time female was giving 7.1 and 6.6 calves on average in the lowland and mid-highland area, respectively (Table 6). This significant discrepancy might be for the prevalence of trypanosomiasis disease which causes the animal to abort or prohibit females to give birth. The Borana pastoralism is traditionally milk dependent production systems (Pratt, et al., 1997) which have been under a critical pressure of diversifying into other livestock species (small ruminant and camel) consequent upon changing climatic and ecological conditions. The current assessment of the productive performance cattle also revealed that the lowland and mid-highland area of Borana were producing varying amount of milk for various purposes.

Table 6. Productive performance of dairy cattle across different agro-ecologies of Borana Zone.

\begin{tabular}{llcc}
\hline Productive traits & Agro-ecology & N & Mean \pm SD \\
\hline \multirow{2}{*}{ Number of calves per reproductive life time } & Lowland & 109 & $7.07 \pm 0.24$ \\
& Mid-high land & 57 & $6.6 \pm 0.30$ \\
& Lowland & 109 & $8.4 \pm 2.2$ \\
Lactation length (Months) & Mid-highland & 57 & $8.8 \pm 1.8$ \\
& Lowland & 109 & $1.85 \pm 0.75$ \\
Milk yield during wet season (liter/day) & Mid-high land & 57 & $1.10 \pm 1.25$ \\
\multirow{2}{*}{ Milk yield during dry season (liter/day) } & Lowland & 109 & $0.35 \pm 0.75$ \\
\hline
\end{tabular}

$\mathrm{N}$ refers to Number of Respondents and SD refers to Standard Deviation

Hence, average daily milk per cow was 1.85 and 1.10 liter during the wet season and 0.35 and 0.95 liter during the dry season of the lowland and mid-highland area, respectively (Table 6). The milk production is inline with the report of Land O'Lakes, Inc. (2010) which indicated the productivity of dairy herd is low with average milk yield of 1.3 liter - 1.54 liter per day for an average lactation period of $180-210$ days. The discrepancy of milk yield of lowland and mid-highland area was probably due to the better genetic merits of the cattle for milk production in the former area and relatively more availability of cattle feed, specifically during the respective dry season, of the later area.

\subsection{The Calving Pattern and Breeding Seasons}

The recall of the respondents on the rank of average annual calves of the last two years indicated seasonal variation in calving pattern of both agro-ecologies with the most frequent calving occurred at the middle and set out of main rainy seasons of the lowland and mid-highland agroecologies, respectively (Table 6). 
Table 7. Rank of calving pattern of different agro-ecologies of Borana zone.

\begin{tabular}{lcccccccc}
\hline \multirow{2}{*}{ Months } & Rank 1 & $\begin{array}{c}\text { Lowland } \\
\text { Rank 2 }\end{array}$ & Rank 3 & Index & Rank 1 & Rank 2 & Rank 3 & Index \\
\hline September & 0.00 & 0.00 & 5.65 & 0.013 & 53.80 & 72.30 & 18.15 & 0.740 \\
October & 1.95 & 4.55 & 6.35 & 0.048 & 75.20 & 54.30 & 23.90 & 0.818 \\
November & 0.00 & 3.85 & 4.00 & 0.026 & 67.80 & 48.75 & 38.60 & 0.775 \\
December & 0.00 & 0.00 & 0.00 & 0.000 & 5.60 & 12.70 & 16.85 & 0.135 \\
January & 0.00 & 0.00 & 0.00 & 0.000 & 1.80 & 2.40 & 4.50 & 0.034 \\
February & 0.00 & 0.00 & 2.00 & 0.004 & 0.00 & 0.00 & 4.75 & 0.011 \\
March & 2.80 & 28.55 & 80.45 & 0.327 & 0.00 & 0.00 & 0.00 & 0.000 \\
April & 82.80 & 57.60 & 19.20 & 0.858 & 0.00 & 0.00 & 0.00 & 0.000 \\
May & 15.60 & 58.70 & 42.30 & 0.463 & 0.00 & 2.45 & 3.00 & 0.018 \\
June & 0.00 & 0.00 & 12.45 & 0.028 & 3.60 & 3.80 & 4.00 & 0.051 \\
July & 0.00 & 0.00 & 0.00 & 0.000 & 7.80 & 8.00 & 18.60 & 0.132 \\
August & 0.00 & 0.00 & 0.00 & 0.000 & 35.40 & 38.80 & 55.75 & 0.547 \\
\hline
\end{tabular}

Hence, March to May for the lowland were the principal calving season where April was the most concentrated month for calving followed by May and March in the lowland agro-ecology. On the other hand, September to November was the main months of calving for the midhighland area where no significant variation was observed among months of calving. These are the periods of the year when the grass for grazing is abundant for the respective agro-ecologies that favors the reproduction of cattle. Kanuya et al (2006) also reported that seasonal pattern of calving could be an adaptive physiological mechanism by the indigenous animals developed over many years where calving occurs at a time of plentiful feed including easily availability of drinking water. The occurrence of peak calving rate in the aforementioned months of lowland and mid-highland area implied that most conception took place between June and July for the former and December and January of previous year for the later agro-ecology. Those breeding seasons are when the animals have access to regrown natural pasture due to short rainy season of lowland area and crop residues and other leftover basal feed after harvesting in the mid-highland agro-ecology.

\section{Conclusion and Recommendations}

In the light of the findings this survey, it can be concluded that cattle are the primary livestock species for milking in both agro-ecologies, followed by the recently emerging camel. Based on the age and sex of the animal there were different herd structure of cattle at varying proportion. Higher proportion of cows and young animals in the herds of lowland than mid-highland marks the significance of cattle production, and large crops of calves for rapid herd growth and high milk production in the respective area. Therefore, any livestock improvement endeavor planned in the zone need to highly consider cattle so as to alleviate milk deficit of the country.

With varying proportion depending on the agro-ecologies and the wealth status of the community, the existence of different strains of Borana cattle like Qorti, Gelaba and Qorti cross Gelaba, and cattle type of neighboring zone like Guji and Konso were recognized in both agro-ecologies. Qorti was believed to be the true and preferred strain both agro-ecologies however it was at decreasing trend because of the climate change and the frequently recurring droughts combined with shrinkage of grazing land. Despite the lower ratio of increment in the mid-highland, the trend for Gelaba was the reverse due to better resistance to aforementioned factors. Appropriately enhancing the husbandry practices and coping with natural disaster, the trend for Qorti has to be improved since it is relatively potential in milk and meat production, and fetching attractive price up on life animal sell. On the other hand, all stockholders should act on accessing Qorti strain that was also the limiting factor for the community to own the animal.

Communal herding practice in the lowland, and privatization of grazing system and traction practices in the mid-highland were the consequence for less ratio of breeding bull to total herd. Most Borana community was indigenously knowledgeable in selecting better performing breeding male and female for milk production at calf age while others were doing so when the animals were about to sexual maturity. Uncontrolled mating mechanism because of communal grazing system and the culture of the community that forced them to permit their bull to serve female of other and their female to be served by others bull in case they did not absolutely have their own bull or theirs was not attractive was the predominant causes for inbreeding which was the risk of cattle production. Improving the awareness about the merits of controlled mating mechanism and capacitating on inbreeding control system should be an area of intervention.

Age of sexual maturity, first calving and calving interval of Borana cattle of both agro-ecologies was relatively longer than the similar cattle type under improved management practices but shorter than different cattle type under similar husbandry practices. Shortening of age of sexual maturity, first calving and calving interval, and elongation of reproductive life time and higher milk production performance of lowland than mid-highland area were the outcome of cattle strain variation. Therefore, enhancing husbandry practices and combating manmade and natural factors that possibly reverse the scenarios are recommendable tools to further improve the reproductive and productive performances of Borana cattle. 


\section{Acknowledgements}

I would like to acknowledge Oromia Agricultural Research Institute for its financial support. Grateful appreciation also remained to the staff members of Yabello Pastoral and Dryland Agriculture Research Center namely Mr. Nasir Siraj, Mr. Abebe Olkeba, Dr. Bedane Adane and Mr. Mohammed Ibrahim for their cooperation during data collection; Ms. Nedifo Gufu for her unreserved support during data entry and Mr. Eshetu Teshome, the current manager of the center, for his non tedious inspiration to mobilize the required resources for finalizing this document. Lastly, but not the least, I passionately grant special thanks to the community of Borana zone for their willingness to devote their precious time and thereby share their immense indigenous knowledge in the subject matter.

\section{References}

[1] Ababu Dekeba, Warkneh Ayalew, P.B. Hedge and Zerihun Taddesse (2006). Performance of the Abernosa Ranch in the production of Ethiopian Boran x Holstein crossbreed dairy heifers in Ethiopia.

[2] Abebe O. (2009). Cattle production in high and low market access areas in the Borana pastoral system of southern Ethiopia. MSc. Thesis Presented to the College of Dryland Agriculture and Natural Resources of Mekelle University, Ethiopia.

[3] ACTESA (Alliance for Commodity Trade in Eastern and Southern Africa) (2011). Ethiopia livestock value chain base line study.

[4] Adugna Tolera and Aster Abebe (2007). Livestock production in pastoral and agro-pastoral production systems of southern Ethiopia. Department of Animal and Range Sciences, College of Agriculture, Hawassa University, Ethiopia.

[5] Armstrong J.B. (2006). Inbreeding: Why we will not do it? Accessed on February 05, 2010 from http://www.parispoodles.com/Inbreeding.html.

[6] Ayana Angassa and Fekadu Beyene (2003). Current Range Condition in Southern Ethiopia in Relation to Traditional Management Strategies: The Perceptions of Borana
Pastoralists. Department of Animal Production and Rangeland Management, Awassa College of Agriculture, Debub University, Awassa, Ethiopia.

[7] Ayana Angassa and Oba G. (2007). Relating long term rainfall variability to cattle population dynamics in communal rangelands and a government ranch in southern Ethiopia. Agricultural systems, 94: 715 - 725.

[8] Desta S. and Coppock D.L. (2002). Cattle population dynamics in the southern Ethiopian rangelands, $1987-97$. Journal of Range Management, 55: $439-451$.

[9] Falconer, D.S. and T.F.C. Mackay, (1996). Introduction to Quantitative Genetics. $4^{\text {th }}$ ed. Harlow, England, Longman. pp. 438 .

[10] Kamara A. (2004). Chapter 3: Ethiopia, In: Mc Carthy, N. (ed.), Managing Resources in Erratic.

[11] Environments: An Analysis of Pastoralist Systems in Ethiopia, Niger, and Burkina Faso. Research Report 35, Washington, IFPRI, 26-38.

[12] Kanuya N. L., Matiko M.K., Nkya R., Bittegeko S.B.P., Mgasa M.N., Reksen O. and Ropstad E., (2006). Seasonal changes in nutritional status and reproductive performance of zebu cows kept under a traditional agro-pastoral system in Tanzania. Journal of Tropical Animal Health and Production. Volume 38. Issue 6. Pp 511- 519.

[13] Land O'Lakes, Inc. (2010). The Next Stage in Dairy Development for Ethiopia: Dairy Value Chains, End Markets and Food Security. USAID Cooperative Agreement No. 663-A-00-05-00431-00.IDD.

[14] Okeyo A.M., Mosi R.O. and Langat L.K.I. (1998). Effects of parity and previous parous status on reproductive and productive performance of Kenya Boran cows. Tropical Agriculture (Trinidad) 75(3):384-389.

[15] Pratt D., F.Le Gall and Cornelis De Haan (1997). Investing in Pastoralism: Sustainable Natural Resource Use in Arid Africa and Middle East. World Bank Technical Working Paper No 365, Washington D.C.: World Bank.

[16] Zelalem Nemera (2012). Borana pastoralists' indigenous knowledge in cattle breeds management. Proceedings of the $19^{\text {th }}$ annual conference of the Ethiopian society of animal production (ESAP) held in Addis Ababa, Ethiopia, December 15 to $17,2011$. 